\title{
Article
}

\section{Integrative approaches to investigating human-natural systems: the Baltimore ecosystem study}

\author{
Mary L. Cadenasso ${ }^{a}$, Steward T.A. Pickett ${ }^{\mathrm{b}}$, Morgan J. Grove ${ }^{\mathrm{c}}$ \\ a Ecologist, Hixon Center for Urban Ecology, FES, Yale University, 205 Prospect Ave, New Haven CT 06511, USA \\ b Ecologist, Institute of Ecosystem Studies, Box AB, Millbrook NY 12545, USA \\ c Social Scientist, USDA Forest Service, Northeastern Research Station, George D. Aiken Forestry Sciences Laboratory, \\ 705 Spear St., PO Box 968, Burlington VT 05401, USA
}

\begin{abstract}
La ville de Baltimore est ici assimilée à un écosystème dans lequel interagissent des complexes biotiques et abiotiques. Cela suppose une reconnaissance explicite de la composante humaine de cet écosystème, y compris dans ses dimensions culturelles et institutionnelles. Dans cette perspective, les auteurs rendent compte d'une expérience interdisciplinaire en construction, en quête de méthodes, de concepts, de questions de recherche - et nous invitent à croiser nos pratiques de part et d'autre de l'Atlantique, comme le souligne le commentaire à cet article.
\end{abstract}

La Rédaction

\section{Keywords:}

urban ecology; spatial heterogeneity; patch dynamics; riparian; management

\begin{abstract}
This paper presents an overview of the research approaches used to study metropolitan Baltimore (Maryland, USA) as an ecological system. The urban ecosystem is a complex of biophysical, social, and built components, and is studied by an interdisciplinary team of biological, social, and physical scientists, and urban designers. Ecology "of" the metropolis is addressed rather than restricting research to ecology of green areas "in" the metropolis. The project applies standard ecological approaches such as the ecosystem, watersheds, and patch dynamics to the metropolitan area. In addition to research, the project conducts education at all levels and engages with communities and local policy makers and managers. Three broad questions guide the project, and focus on 1) the structure of the system from biophysical, social, and built perspectives, 2) the fluxes of energy, matter, population, and capital, and 3) the feedback between ecological information and environmental quality. We present examples of results focusing on each question.
\end{abstract}

Résumé - Étude intégrée des systèmes homme-nature : l'écosystème de Baltimore, Maryland, USA. Cet article synthétise l'étude d'une métropole vue comme un écosystème - la ville de Baltimore. Les investigations ont porté sur l'écologie de la métropole entière et non seulement sur l'écologie des zones vertes dans la métropole. Trois questions majeures sous-tendent le projet : 1) la structure du système aux points de vue biophysique, social et bâti ; 2) les flux d'énergie, de matière, de population et de capitaux; 3) la rétroaction entre l'information écologique et la qualité de l'environnement. En réponse à la première question, nous montrons qu'il est mieux rendu compte de l'hétérogénéité urbaine par une classification qui intègre, au lieu de les séparer, les couverts bâtis et végétalisés. En réponse à la deuxième question, nous montrons que les zones riveraines urbaines ne réduisent pas la pollution par les nitrates comme dans les régions agricoles. La structure de la végétation riveraine est induite par des processus sociaux différents de ceux qui déterminent la structure de la végétation des parcelles urbaines, que ces dernières soient privées ou qu'elles relèvent de servitudes des passage publics, suggérant que les gens se soucient peu de la santé des écosystèmes riverains urbains. Ce constat a conduit les décideurs à proposer une politique de zones vertes pour améliorer la qualité des eaux de ruissellement et diminuer leurs flux lors des orages. Ceci renvoie à la troisième question sur l'amélioration de la qualité de l'environnement urbain à partir de nouvelles informations écologiques.

Corresponding author:

M.L. Cadenasso, Mary.Cadenasso@yale.edu 
Metropolitan regions consist of patterns and processes typically studied and understood within distinct disciplinary realms such as social science, economics, hydrology, urban planning and design, and ecology. In addition to being multidisciplinary, the patterns and processes also occur across multiple scales. These two features pose a terrific challenge to understanding urban systems and the challenge requires unifying concepts, approaches, and tools.

The purpose of the Baltimore Ecosystem Study (BES) is to study the metropolitan area of Baltimore, Maryland, USA, as an ecosystem. Therefore, all the components of the system must be incorporated into our understanding, not just the green components with which ecologists are so familiar. As part of the Long-Term Ecological Research network, funded by the US National Science Foundation with substantial in kind support from the US Forest Service, the BES unites researchers from biological, physical, and social sciences. Such an integrative approach is novel in the United Sates, and the goal of this paper is to provide an overview of concepts and guiding research questions that structure the BES. The questions are necessarily broad to facilitate application across disciplines and scales and they address system structure, fluxes, and understanding and application. Individual research projects specify the questions for their own data collection. We provide linked examples that focus on landscape heterogeneity, riparian function, and "re-greening" management strategies. A new land cover classification is presented to describe heterogeneity by integrating components of the landscape that result from both ecological and social processes. We focus on altered riparian function as an example of research on fluxes. Finally, lessons learned from the riparian research are used to demonstrate the link between research and understanding and application. Though examples of each question are provided, presenting data is not our primary aim: instead we focus on the approach and cross disciplinary integration that has been necessary for building our understanding.

\section{Fundamental concept}

\section{The nature of urban}

Urban is a surprisingly difficult term to define. Demographers define it in terms of human population density. Specifically, urban areas are defined (US Census Bureau, 1995) as "One or more places ('central place') and the adjacent densely settled surrounding territory ('urban fringe') that together have a minimum of 50000 persons. The urban fringe generally consists of contiguous territory having a density of at least 1000 persons per square mile" (385 persons $/ \mathrm{km}^{2}$ ). However, the official
US definitions account for the differences in how States define municipalities. The styles of urban settlement likewise differ among countries. Therefore, the United Nations (2001) accepts the definitions of urban used by each nation. Nor are definitions temporally uniform. In the United States, definitions of urban now rely on commuting connections as well as on the time honored criteria of population density and the clustering of buildings.

Official definitions of urban are motivated by policy needs and, consequently, these definitions may not be appropriate for an ecological understanding of urban ecosystems. Ecology needs to develop its own definition of urban, informed by ecological theory to serve its research needs. In the United States, we are still far from this goal. In part, this is because the ecological theory to be used is still developing. Indeed, how to link ecological theory with principles from the social sciences, civil engineering, and urban design to forge a more inclusive theory of urban ecological systems is a major need.

Adding difficulty to defining urban is the heterogeneous nature of urban areas. Some cities encompass large forest or desert parks or have agricultural inholdings. Heterogeneity also results from sprawl of urban areas in amoeboid or spider-like forms across rural lands. This spread establishes complex gradients extending from dense central cities, through industrial, transportation, residential, and commercial land covers. To accommodate such heterogeneity, ecologists introduced the urbanrural gradient concept (McDonnell and Pickett, 1990). A frequently misunderstood but important point is that these gradients are not necessarily linear transects on the ground. Rather they are abstract orderings of changes in land cover, land use, human activity, and the fluxes of capital, energy, material, and information in and around cities. McIntyre et al. (2000) suggest that the complexity and variety of urban-rural gradients are benefits that ecologists can exploit in studying urban systems. It is necessary to state the features of the gradient to be used in a particular study, how they are quantified, and how they change over space.

What do we mean by urban in the Baltimore Ecosystem Study? In the most inclusive sense, urban is an ecological-social phenomenon and refers to all types of land cover that are in densely built regions or that are controlled by social processes centered in those regions. Human population will be high - generally 193 to 385 persons $/ \mathrm{km}^{2}$. In this broad sense, urban is equivalent to metropolitan and incorporates many elements of heterogeneity. A narrower sense of urban sets it in contrast to both suburban and rural. All of these levels of urbanization are used in BES for comparisons across the metropolitan area. Each research team defines the levels as it sees fit, although it must specify the factors or attributes used. This specification is the solution suggested by McIntyre et al. (2000) and Theobald (2004). There are 
additional concepts that help structure urban ecological studies. We turn to watersheds next.

\section{Urban watersheds}

We use the watershed approach in Baltimore because of its proven success and general application in ecology (e.g. Likens and Bormann, 1995). Applying it to an urban watershed is a test of its utility in a habitat previously neglected by ecologists. The watershed approach measures stream flow and water chemistry at the lowest point in a catchment. The output integrates influences from adjacent terrestrial systems and instream processes. Large catchments can be divided hierarchically into component catchments. The contribution of each subcatchment to the output of the larger catchment can be assessed. Therefore, the watershed approach determines the role that the structure of a catchment plays in its function.

In addition, watersheds are increasingly a management focus. The Chesapeake Bay, on which Baltimore is located, is the largest estuary in the United States, drawing on a watershed that intersects seven states. Although it is vast, the Bay is shallow, and pollution has reduced its water and habitat quality (Kennedy and Mountford, 2001). Policy and management decisions are promulgated for the entire watershed to reduce nitrogen pollution and sedimentation to the bay ${ }^{1}$.

\section{Patch dynamics}

Additional aspects of the structure-function relationship are revealed by patch dynamics. Patch dynamics recognizes that all parts of a landscape, including catchments, can be spatially heterogeneous. At a particular scale, the heterogeneity can be resolved into patches that differ from each other. Although the patches may be heterogeneous at finer scales, at the scale of interest they are internally homogeneous relative to one another (Cadenasso et al., 2003). Examples include forest and field patches discriminated at the scale of $\mathrm{km}$, or, at the scale of meters, tree fall pits and mounds in old growth forests (Pickett and White, 1985). In urban systems, patches may be recognized by differences in architecture from one block to the next, or by the contrast between commercial and residential areas, or by differences in social structure across a city (Grove et al., 2005). It is important to recognize that patches in urban systems can be characterized by biophysical structures, by social structures, by built structures or by a combination of the three (Cadenasso et al., 2006).

Patches also change in time. For example, a city patch possessing a tree canopy will change as the trees mature

${ }^{1}$ Chesapeake Bay Program, http://www.chesapeakebay.net/ and senesce, reducing canopy extent. Patches can also exhibit social dynamics, as when a neighborhood of predominantly older residents shifts to dominance by young families. In these contrasting states, the patch makes different demands on the infrastructure and government. For example, young families may want playgrounds and access to schools while elderly residents may demand access to health services and passive recreation. The social requirements of specific patches will thus shift through time.

\section{Ecology "in" versus ecology "of" cities}

The different definitions of urban, the formative state of urban ecological theory, and the complexity of gradients of heterogeneity all give urban ecological studies great breadth and flexibility. Urban ecological studies range from traditional studies conducted in and near cities, to studies that take an ecological perspective of the entire metropolis. The first, more focused approach is labeled ecology "in" cities. The second, more inclusive approach is labeled ecology "of" cities (Pickett et al., 1997).

Both approaches are useful for a full ecological understanding of metropolitan ecosystems (Nilon et al., 2003). Ecology in cities focuses on ecologically familiar places parks as analogs of rural forests (e.g. Attorre et al., 1997; Kent et al.,1999), vacant lots as analogs of fields or prairies (Vincent and Bergeron, 1985; Cilliers and Bredenkamp, 1999). Urban streams, rock outcrops, and remnant wetlands invite ecological studies quite similar in scope and method to those conducted in non-urban landscapes. There is a long European tradition of ecological studies in cities (Sukopp et al., 1990; Berkowitz et al., 2003).

Work in the New York City metropolitan region, a precursor to BES, is an example of ecology in cities. Members of the Urban-Rural Gradient Ecology project, led by Dr. Mark McDonnell, discovered that forest stands closer to the core of New York City had higher levels of nitrogen deposition (Lovett et al., 2000), exotic earthworm species (Steinberg et al., 1997), and higher levels of nitrogen turnover (McDonnell et al., 1997; Pouyat et al., 1997; Zhu and Carreiro, 1999) than rural forests. Additional studies showed altered populations of other soil invertebrates and of fungal species (Carreiro et al., 1999). Studies of ecology in cities often ask about the links between biological pattern and process and the social or built environments that influence the green spaces studied. For example, nitrogen processing in forest patches along the New York City gradient correlated best with traffic volume (Medley et al., 1995), a finding explained by the fact that automobile exhaust is the primary source of atmospheric nitrogen input in urban areas. Slightly lower correlations existed for road density and population density in the $16 \mathrm{~km}^{2}$ blocks surrounding each forest. 
The second approach - ecology "of" cities - is newer and therefore less well developed. The approach having the longest pedigree examines the input-output budgets of a city. The budgetary approach has relied on a "closed box" approach to ecosystems. Inputs and outputs are measured, and the processes within the system are tacitly assumed to be homogeneous. This approach is akin to the ecosystem ecology of the 1960s and 1970s and has been used by ecologists (Bormann and Likens, 1967), environmental historians (Cronon, 1991), and social scientists (Stearns and Montag, 1974). The material and energy budget of Hong Kong (Boyden et al., 1981) and the nitrogen budget of New Haven, Connecticut (Burch and DeLuca, 1984) are examples. The dearth of interdisciplinary experts noted by Boyden et al. (1981) and the apparent lack of interest by mainstream ecology have thwarted this approach to cities. However, the Baltimore Ecosystem Study (BES) and the Long Term Ecological Research (LTER) program in Phoenix, Arizona, have begun developing nitrogen budgets for their urban ecosystems (Baker et al., 2001; Groffman et al., 2004).

Ecology of cities in its contemporary form takes its cue from new approaches to ecology in general and ecosystem ecology in particular. It also benefits from relatively newer specialties, such as landscape ecology which brings a focus on the function of spatial heterogeneity. It further benefits from increasing interdisciplinary work and training. Together, these developments make the inclusive approach to ecology of cities very different from the examples from the 1970s and early 1980s. There are several reasons for this difference. First, the ecology of cities addresses the whole range of habitats in metropolitan systems, not just the green spaces which are the focus of ecology "in" cities. Second, spatial heterogeneity, expressed as gradients or mosaics, is a key hypothesis for explaining interactions and changes in the city. Finally, the role of humans at various levels of social organization, from individuals through households and ephemeral associations, to complex and persistent agencies, is linked to the biophysical features of the metropolis. The urban ecosystem is thus modeled in a different way than traditionally. Humans and their institutions are a part of the ecosystem, not simply external, negative influences. This opens the way towards understanding feedbacks between the biophysical and human components of the system, towards placing them in their spatial and temporal context, and towards examining their role on ecosystem inputs and outputs at various scales. That is the goal of BES.

\section{Why Baltimore?}

Baltimore, Maryland, a metropolitan area of approximately 3 million people, comprises the City of Baltimore, and the five surrounding counties (Fig. 1). Baltimore developed as a shipping port, specializing in grain and tobacco. When the first railroad in the US was built from Baltimore westward into the coal fields of Pennsylvania, the city added heavy industry to its economic base. After World War II, Baltimore experienced a decline in urban population with migration to the suburbs, and a shift from industry to a service and information economy. The historical legacies and ongoing changes in the location of population, power, and investment make Baltimore a dynamic system, with ecological and social contrasts to explore both in the older city and on the suburban fringe.

One advantage offered by Baltimore is its recognized watersheds. In part the attention to watersheds reflects the proximity of the Chesapeake Bay. The federal mandates to reduce nitrogen loading to the Bay have called attention to the water quality in the Chesapeake's tributaries. We have focused on three streams draining the city of Baltimore and much of adjacent Baltimore County. They present a range of environments, from industrial and commercial lands along the Inner Harbor, to established residential patches of varying densities, structures, and ages, to commercial strips and zones, to stable agriculture, rural forests preserves, and agricultural land actively being converted into suburban housing and business uses. Small catchments have been selected in each of these areas, and the cumulative effect of urbanization on water quality and the pattern of water flow has been sampled and monitored to assess the ecological structure and function throughout the metropolis (Fig. 2).

In addition to the biophysical reasons for selecting Baltimore, there are social reasons. The problem of access, permission, and multiplicity of interested parties was solved in Baltimore by a long history of environmental work with urban natural resource agencies and local communities. Initiated by Prof. William R. Burch, Jr., of Yale University in collaboration with the late Dr. Ralph Jones, then Director of the Baltimore City Department of Recreation and Parks, a program of community development combined with community forestry has existed in Baltimore since 1989 (Burch and Grove, 1993). The social networks that program established and nurtured, provide a strong foundation for the scientific research of BES.

Three examples of the social capital we rely on in Baltimore make the point. First is the Urban Resources Initiative (URI), which began as a partnership of the City of Baltimore Department of Recreation and Parks, The Parks \& People Foundation (PPF), and Yale University's School of Forestry and Environmental Studies. The URI Coordinator insures that the scientific and community and agency concerns are complementary. They also integrate the greening and educational activities of PPF with work in BES, bringing scientists into greening projects and programs in schools and nature centers. 


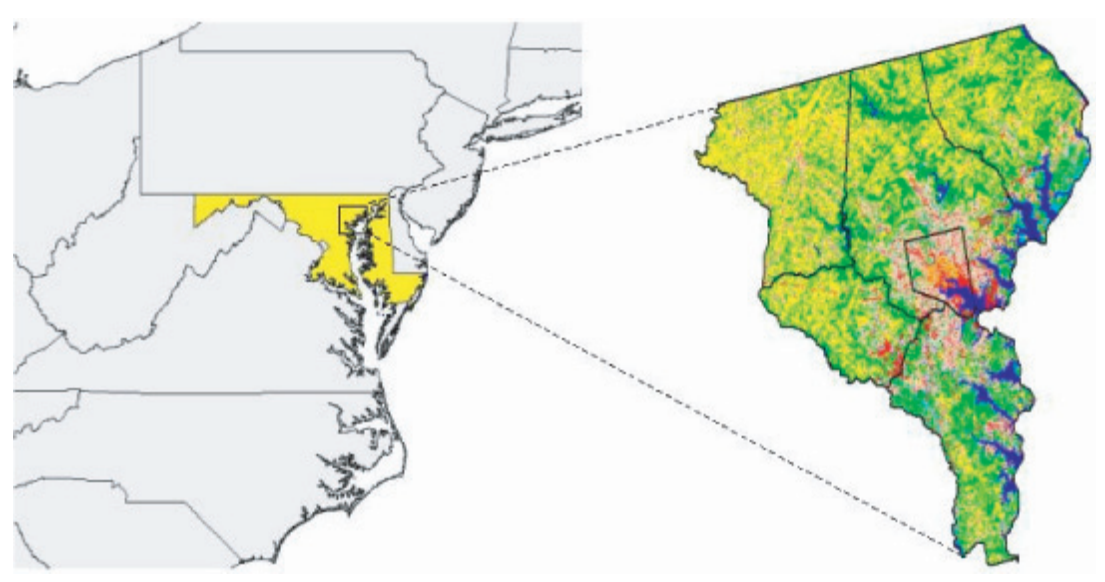

Fig. 1. Location of metropolitan Baltimore, Maryland. Left panel: the State of Maryland, and the Chesapeake Bay; right panel: the five county metropolitan area surrounding Baltimore City. Red $=$ commercial land cover, $\tan =$ residential areas, brown $=$ barren and wetlands, light green $=$ agriculture, green $=$ forests, and blue $=$ water.

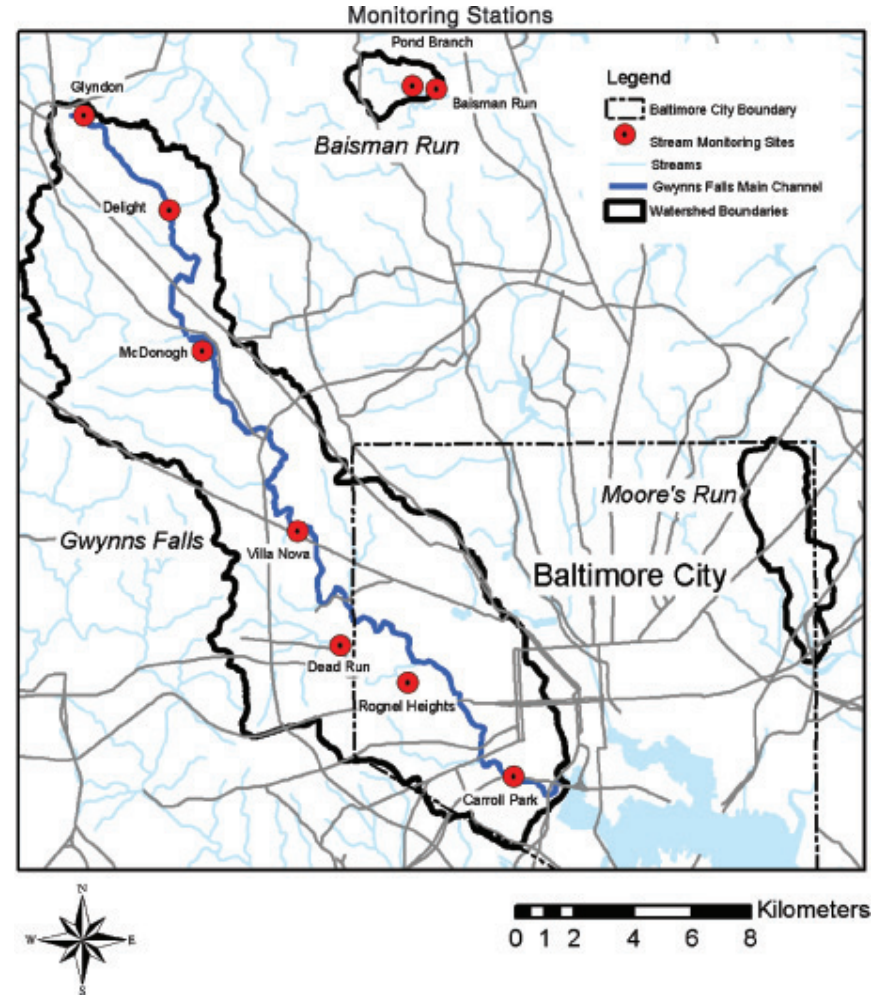

Fig. 2. Key watershed based sampling areas of the Baltimore Ecosystem Study LTER. Baisman Run contains the forested reference catchment of Pond Branch, and a low density suburban catchment. The Gwynns Falls catchment samples suburban headwaters, residential and agricultural lands in middle reaches, and old residential, commercial, and industrial coverages in the lower reaches. Subwatershed sampling stations represent these different coverages, while the mainstem sampling stations at Carroll Park, Villa Nova, Delight, and Glyndon sample cumulative changes in water flow and quality.

Second, PPF organized and facilitates the Revitalizing Baltimore Technical Committee and the Watershed Linkages Committee. These committees encourage communication between policy makers, managers, community leaders, and researchers. Communicating with these stakeholders helps BES researchers to know agency concerns, and to learn in advance where public projects and private development are slated so that research can be planned accordingly. These committees also help communicate scientific results to those who can use them. Without this firm foundation, it would be exceedingly difficult, if not impossible, to conduct wide ranging, integrative social-ecological research and education in Baltimore. Third is the personal rapport built up by principal investigators in BES who have worked in the neighborhoods of Baltimore for more than a decade. Their "street credibility" is important for the success of BES. These experienced urbanists help educate novice urban researchers to develop a street sense, to know how to access and respect community leaders and social structures, and to make otherwise abstract ecological research relevant to citizens in neighborhoods of all sorts.

Are the approach used in Baltimore and the knowledge gained there relevant to other cities? Clearly, urban areas in different countries, and even in different parts of the United States, differ in their development and their current economic status. However, we expect that the frameworks used in Baltimore should be applicable to other cities. The LTER project in Phoenix, Arizona, uses many of the same conceptual frameworks, and even some of the same sampling strategies (Grimm et al., 2000). In both projects, the patch dynamics concept helps unite the different disciplines. There are some differences in detail, of course. For example, the watershed approach is not used in Phoenix because the flow of surface water is essentially replaced by piped water in that desert metropolis. Similar approaches are being explored through the Urban Ecology Collaborative in Boston, MA, New Haven, CT, New York NY, Pittsburgh, PA, and Washington, DC (www.urbanecologycollaborative.org). It is important that the differences among cities can be explained by overarching theories. Seeking mechanisms underlying the patterns exposes the larger frameworks that may apply to all cities. We turn now to the research questions that put these frameworks to work in BES. 

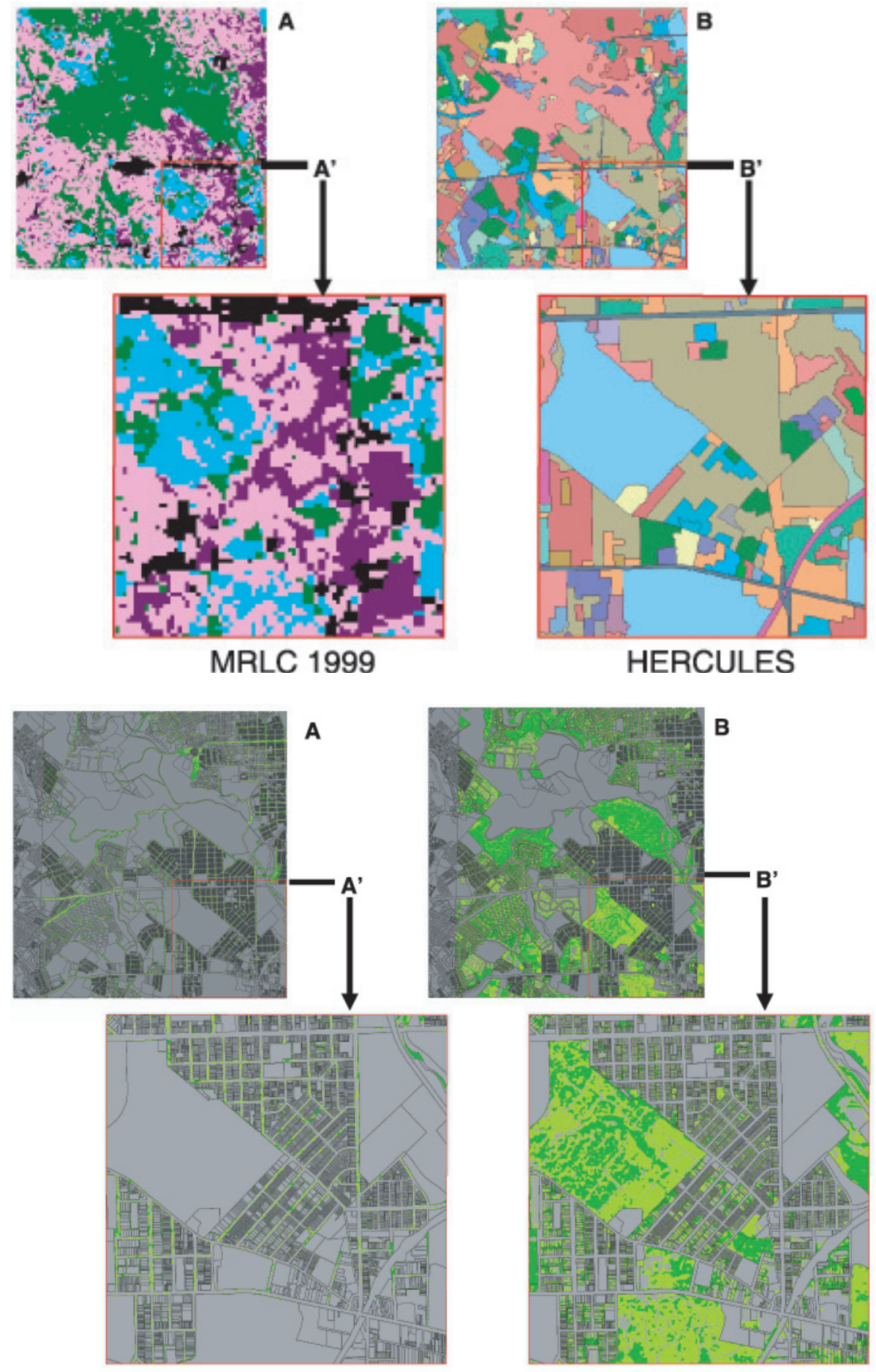

Fig. 3. Comparison of A) MultiResolution Land Cover (MRLC) and B) HERCULES land cover classifications for the Rognel Heights area of Baltimore in 1999. The southeast corner of each classification is enlarged in the lower panels ( $\mathrm{A}^{\prime}$ and $\mathrm{B}^{\prime}$ respectively). MRLC shows forest, low, medium and high intensity residential, and commercial land covers. HERCULES differentiates between structurally dominated patches, vegetationally dominated patches, and patches that have different amounts of impervious surfaces.
Fig. 4. Socially defined patches in the Rognel Heights area of Baltimore City. The patches represent a social structure that affects vegetation. The distribution of grass (light green) and trees (dark green) in each of two social property regimes is shown: panel $A$ shows vegetation located in the public rights of way, while panel $B$ shows vegetation in private parcels. The southeast corner of each map is enlarged in $A^{\prime}$ and $B^{\prime}$ respectively. Such social differentiation is important to how vegetation is managed, and what resources are brought to bear for the purpose. Contrast these socially defined patches with the structural patches in Figure 3.

\section{The research questions}

Three overarching questions guide the research, education, and interactions with the public in BES. The first question addresses the integrated system structure: the second question addresses the fluxes in the system, and suggests the interaction of structure and flux, while the third question deals with how linked ecological and social information can change the metropolitan system. We state each question, and present an example of research that contributes to its answer.

\section{Question 1 - Integrated system structure}

"How do the spatial structures of socio-economic, ecological, and physical features of an urban area relate to one another, and how do they change through 
time?" This question requires the spatial heterogeneity of metropolitan Baltimore to be assessed by the various disciplines involved, but to be modeled in ways that can unify them. We present an example of how we approach the spatial structure.

Spatial structure of urban systems in the United States is often described by land use/land cover classifications. In an effort to standardize nomenclature, Anderson et al. (1976) first presented a classification for the entire nation. This scheme, developed by natural resource scientists, was to compensate for the purely demographic classifications available at the time. As a result, its first division is between vegetated land cover and urban land cover. Additional classifications have been developed but they are derivatives of Anderson's scheme (e.g. FAO, MRLC). The dichotomy between non-built and urban land cover present in all of these schemes poses a problem for understanding cities as ecosystems because urban systems combine built and biophysical components. Not surprisingly, attempts to relate functional ecosystem variables to this kind of classification have shown no relationship (Groffman et al., 2004). The common classification does not account for observation that the change in architecture, vegetation, economic vitality, and social activity occurs over very short distances in cities (Jacobs, 1961; Clay, 1973). This sort of fine grained heterogeneity may have significant ecological implications, in the same way that fine grained heterogeneity affects ecosystems beyond the urban fringe (Hutchings et al., 2000).

We have developed a new classification to capture the fine grained, complex heterogeneity characteristics of urban systems. It resolves the urban structure into classes that reflect the buildings, the presence of massed pavement, and vegetation type and structure. The classification is named HERCULES (High Ecological Resolution Classification for Urban Land and Environmental Systems). The term "resolution" in the title refers to the fineness of classes themselves. The highest hierarchical levels in the classification are 1) Closed tree canopy, 2) Open canopy vegetation with no built structures, 3) Built structures and associated vegetation, and 4) Miscellaneous. Each of these categories is disaggregated based on more detailed characteristics. Closed tree canopies are assigned a class based on the proportion of large and small crowns. Open canopy vegetation is classified by the relative cover of tree, shrub, and herbaceous layers. Patches containing built structures are characterized by building type and density, vegetation structure and proportion cover and the presence of massed pavement.

The comparison of the HERCULES land classification with that based on Anderson et al. (1976) is an example of the power of the integrated approach followed by BES. HERCULES provides a vast and novel data set of urban ecological structure and reveals much greater variety within the urban system (Fig. 3) than do Anderson type approaches. Ongoing work in BES is exploring the relationship of HERCULES to the output of models for water flow and water quality compared to output based on Anderson. Initial results suggest that spatially explicit, detailed cover assessments that include ecological features hypothesized to influence the hydrologic cycle, are better predictors than the standard land use approach. This analysis is not intended as a criticism of the Anderson et al. (1976) model. Rather, we challenge its application to urban ecosystems when the goal is to understand the system from an ecological perspective and we are generating new data to support this challenge.

HERCULES presents one kind of patch array. However, there are many possible ways to describe the spatial heterogeneity of urban ecosystems. The variables collected in the census can be depicted spatially in the same way we have depicted the structural patches discovered using HERCULES. Social data range from the coarse spatial grain of the census, divided into block groups of approximately 400 households, to parcel-level data (Fig. 4). Social and biophysical patch arrays represent two theoretically and practically different ways to see the heterogeneity of the metropolis (cf. Figs. 3 and 4). Ongoing research is examining the functional relationships between these patch arrays (Cadenasso et al., 2006, Grove et al., 2006).

\section{Question 2 - Flux in the system}

"What are the fluxes of energy, matter, human-, built-, and social-capital in an urban system; how do they relate to one another, and how do they change over the long term?" This question coupled with Question 1 implies a functional question: What are the relationships between the integrated structure of the system and the fluxes of the metropolitan system?

An example of the study of flux in BES is the examination of riparian function. In non-urban ecosystems, riparian zones are commonly thought to be buffer zones that reduce pollution in the adjacent streams (Lowrance et al., 1984; Peterjohn and Correll, 1984; Naiman and Décamps, 1997). Forested riparian zones usually convert nitrate to gaseous nitrogen, reducing nitrogen loading to streams. BES researchers wished to know whether this same process was at work in the metropolitan area.

The conclusion is that urban riparian zones are not sinks for nitrate (Groffman and Crawford, 2003). This results from hydrological and geomorphic modification of urban streams. Three factors are at work. One, ground water recharge to water tables in riparian zones is reduced in urban areas due to the impervious surfaces. Two, much of the drainage from the impervious surfaces is channeled not through streams, but through a storm water sewer system. Three, urban hydrology is extremely flashy, which means that during storms floods 
rise quickly and flow at very large volumes for short periods. Such flash floods erode urban streams deep into the substrate, often to bedrock. This deepening of stream channels separates the water table from the floodplains where denitrification would otherwise occur. The riparian soils thus become aerobic, which inhibits the anaerobic process of denitrification (Groffman et al., 2003).

There is a social component to this story of riparian function. In certain areas, nitrogen loading to streams is increased by fertilizer application. Fertilizer use peaks at intermediate home values, and is lower where home values are low or high (Law et al., 2004). This is likely because wealthy homeowners can afford lawn care services, which optimize fertilizer application to maximize profit, while poorer homeowners can devote fewer resources to lawn care. The homeowner applies fertilizer in middle income homes and the application is least likely to be conservative. This observation is one that has stimulated BES researchers to propose an "ecology of prestige" in which household management decisions are driven not by the rationality of environmental impact or of cost, but rather of enhancing membership in a social neighborhood group based on conformance to home maintenance standards and lifestyle choices (Grove et al., 2006).

\section{Question 3 - Understanding and application}

"How can people develop and use an understanding of the metropolis as an ecological system to improve the quality of their environment, and to reduce pollution to downstream air and watersheds?"

BES research showing that urban riparian zones are disconnected from the water table, and hence may not serve as sinks for nitrate pollution, has prompted a new look at management to improve water quality in Chesapeake Bay. Until recently, focus has been on control of point sources of nitrate pollution, and on enhancement of riparian buffers. Because of BES research, managers have suggested that a dispersed strategy to managing water quality may be more successful. As a result, the Chesapeake Bay Program has called for increased tree planting in urban watersheds (M. Galvin, Maryland Department of Natural Resources, Forest Service, pers. comm.). In Baltimore City, the test is being carried out in a 367 ha storm water catchment, Watershed 263. The head of the Waste Water Division of the Baltimore City Department of Public Works, who participates as a collaborator in BES, has set up a greening program in this watershed, facilitated by the PPF and funded through the Forest Service. Water quality and flow are being measured in several subcatchments, including ones in which greening will be pursued immediately, and those which will serve as controls until the greening activities reach them in 10 years. Watershed 263 has a high rate of abandonment and many vacant lots. These parcels present an opportunity to design new storm water infiltration schemes, site trees and other vegetation in hydrologically and socially advantageous ways, and target other aspects of neighborhood revitalization to integrate storm water management. Such integration is important in these underserved neighborhoods to engage community members and promote their involvement in continued support and management of any greening projects undertaken in their neighborhoods. This experiment is an example of the feedback between ecological information and social action and public knowledge driven by BES data.

\section{Conclusions}

The Baltimore Ecosystem Study addresses a metropolitan ecosystem as an integrated, socialecological system (Pickett et al., 1997). Fundamental is the idea that the metropolis and its component areas are ecosystems. The core of the ecosystem concept is the interactions between biotic and abiotic complexes. However, to make the concept work in urban areas, the human component of the biotic complex must be explicitly and subtly recognized. A human ecosystem, as opposed to an ecosystem in the biocentric sense, must account for the structures that people create. As a part of the biotic complex, people add culture, institutions, and the capacity for feedback between environment and institutions through learning, communication, and engineering (Fig. 5). This means that complete understanding of a human ecosystem, even though it is motivated by basic ecological concerns, must include the expertise and collaboration of social scientists as well as biological and physical scientists (Pickett et al., 2001). To knit these disciplines together, we have pursued several integrative concepts and tools:

- Watersheds. All researchers within BES focus their work on our major watersheds. Numerous sampling approaches are used ranging from intact forest outside the city, to inner city streams in culverts. The social environment ranges from wealthy suburbs and exurbs, to underserved inner city neighborhoods. All can be tied together by a comparative and gradient approach to watersheds.

- Patch dynamics. The immense spatial heterogeneity is fodder for comparisons in space, time, and across disciplines. Within each discipline, the urban-rural gradient provides suggestive contrasts in structure, function, and allocation of biotic or social resources. The change in spatial patterns over time also exercises different disciplines. How has the social structure of neighborhoods changed with abandonment? How has the vegetative cover of different neighborhoods changed? What is the relationship between vegetation 


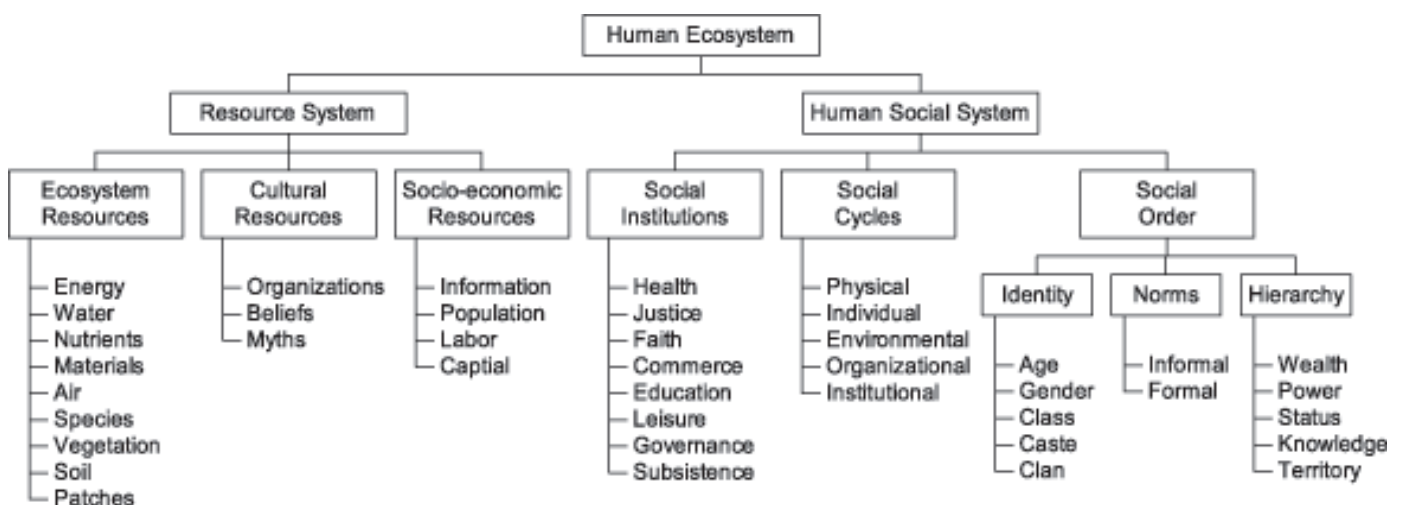

Fig. 5. The Human Ecosystem Framework. This conceptual framework identifies the components of the resource and human social systems required by inhabited ecosystems. The resource system is comprised of both biophysical and social resources. The human social system includes social institutions, cycles, and the factors that generate social order. This is a framework from which models and testable hypothesis suitable for a particular situation can be developed. It is used to organize thinking and research and is a valuable integrating tool for the BES. Modified from Machlis et al. (1997), based on additions by Pickett et al. (1997).

change and social change? These questions are examples of the trend toward interdisciplinary temporal comparisons. All are based on an explicit documentation of spatial contrasts in the system as described under Question 1.

- The Human Ecosystem Framework (Fig. 5). This framework organizes multidisciplinary approaches (Machlis et al., 1997). It recognizes that inhabited, built, and managed systems have social and cultural resources and a social system that comprises institutional structures, social hierarchies, and social dynamics. Feedbacks can exist between components of all of these levels. The framework lays out the kinds of interactions and structures that our integrated models must consider. No one model will contain all components and as our information base increases, we are able to examine higher orders of interaction among components and to assign relative importance to components specified in the framework. The framework supplies a hook for each researcher and is, at this point, a distant target for integration. However, it is important to keep the target in clear view.

- Quarterly science and education meetings. These meetings explore a topic that brings together different disciplines, and lays out future research options. Managers, policy makers, and community leaders participate in these meetings, allowing us to understand new and emerging problems that can stimulate ecological research.

- Participatory action research (Burch and DeLuca, 1984). This requires that researchers and managers, policy makers, and citizens jointly decide on research needs and approaches. We strive to be open to the insights and concerns raised in our meetings with the Revitalizing Baltimore Technical Committee, the Watershed Linkages Committee, and in regular interactions with leaders and practitioners from state, county, and city agencies. Our watershed and riparian research is the result of both scientific expertise and the desire to test processes that are known to exist in non-urban ecosystems, but it also results from our growing understanding of the knowledge, needs, and concerns of citizens and government.

BES is both an integrated research platform for understanding the city and metropolis as an ecosystem, but also an ongoing experiment in integrating disparate disciplines and the concerns of science and society to build compelling ecological research.

\section{Acknowledgements}

Amanda Holland prepared several of the figures. We thank our colleagues and collaborators in the Baltimore Ecosystem Study LTER for sharing their insights. We gratefully acknowledge the National Science Foundation (\#DEB-9714835), and the US Forest Service Northeastern Research Station for support.

\section{References}

Anderson, J.R., Hardy, E.E., Roach, J.T., Witmer, R.E., 1976. Land use and land cover classification systems for use with remote sensor data, USGS professional paper 964.

Attorre, F., Stanisci, A., Bruno, F., 1997. The urban woods of Rome, Plant Biosystems, 131, 113-135.

Baker, L.A., Hope, D., Xu Y., Edmonds, J., Lauver, L., 2001. Nitrogen balance for the Central Arizona-Phoenix ecosystem, Ecosystems, 4, 582-602

Berkowitz, A.R., Nilon, C.H., Holweg, K.S. (Eds), 2003. Understanding Urban Ecosystems: A New Frontier for Science and Education, New York, Springer-Verlag.

Bormann, F.H., Likens, G.E., 1967. Nutrient cycling, Science, 155, 424-429. 
Boyden, S., Millar, S., Newcombe, K., O'Neill, B., 1981. The Ecology of a City and Its People: The Case of Hong Kong, Canberra, Australian National University Press.

Burch, W.R., Jr., De Luca, D., 1984. Measuring the Social Impact of Natural Resource Policies, Albuquerque, University of New Mexico Press.

Burch, W.R., Jr., Grove, J.M., 1993. People, trees, and participation on the urban frontier, Unasylva, 44, 19-27.

Cadenasso, M.L., Pickett, S.T.A., Weathers, K.C., Jones, C.G., 2003. A framework for a theory of ecological boundaries, BioScience, 53, 750-758.

Cadenasso, M.L., Pickett, S.T.A., Grove, J.M., 2006. Dimensions of ecosystem complexity: heterogeneity, connectivity, and history, Ecological Complexity, 3, 1-12.

Carreiro, M.M., Howe, K., Parkhurst, D.F., Pouyat, R.V., 1999. Variation in quality and decomposability of red oak leaf litter along an urban-rural gradient, Biology and Fertility of Soils, 30, 258-268.

Cilliers, S.S., Bredenkamp, G.J., 1999. Analysis of the spontaneous vegetation of intensively managed urban open spaces in the Potchefstroom Municipal Area, North West Province, South Africa, South African Journal of Botany, 65, 59-68.

Clay, G., 1973. Close Up: How To Read the American City, New York, Praeger Publishers.

Cronon, W., 1991. Nature's Metropolis: Chicago and the Great West, New York, Norton.

Grimm, N.B., Grove, J.M., Pickett, S.T.A., Redman, C.L., 2000. Integrated approaches to long-term studies of urban ecological systems, BioScience, 50, 571-584.

Groffman, P.M., Bain, D.J., Band, L.E., Belt, K.T., Brush, G.S., Grove, J.M., Pouyat, R.V., Yesilonis, I.C., Zipperer, W.C., 2003. Down by the riverside: urban riparian ecology, Frontiers in Ecology and Environment, 1, 315-321.

Groffman, P.M., Crawford, M.K., 2003. Denitrification potential in urban riparian zones, Journal of Environmental Quality, 32, 1144-1149.

Groffman, P.M., Law, N.L., Belt, K.T., Band, L.E., Fisher, G.T., 2004. Nitrogen fluxes and retention in urban watershed ecosystems, Ecosystems, 7, 393-403.

Grove, J.M., Burch, W., Jr., Pickett, S.T.A., 2005. Social Mosaics and Urban Forestry in Baltimore, Maryland, in Lee, R.G., Field, D., Burch, W.R., Jr. (Eds), Community and Forestry: Continuities in the Sociology of Natural Resources, Seattle, University of Washington Press.

Grove, J.M., Cadenasso, M.L., Burch, W.R., Jr., Pickett, S.T.A., Schwarz, K., Wilson, M.A., Boone, C.G., 2006. Data and methods comparing social structure and vegetation structure of urban neighborhoods in Baltimore, Maryland, Society and Natural Resources, 19, 2, 117-136.

Hutchings, M.J., John, E.A., Stewart, A.J.A. (Eds), 2000. The Ecological Consequences of Environmental Heterogeneity, Malden (MA), Blackwell Science.

Jacobs, J., 1961. The Death and Life of Great American Cities: The Failure of Town Planning, New York, Random House.

Kennedy, V.S., Mountford, K., 2001. Human influences on aquatic resources in the Chesapeake Bay watershed, in Curtin, P.D., Brush, G.S., Fisher, G.W. (Eds), Discovering the Chesapeake: The History of an Ecosystem, Baltimore, The Johns Hopkins University Press, 191-219.
Kent, M., Stevens, R.A., Zhang, L., 1999. Urban plant ecology patterns and processes: a case study of the flora of the City of Plymouth, Devon, UK, Journal of Biogeography, 26, 12811298

Law, N.L., Band, L.E., Grove, J.M., 2004. Nitrogen input from residential lawn care practices in suburban neighborhoods in Baltimore County, Maryland, Journal of Environmental Management, 47, 737-755.

Likens, G.E., Bormann, F.H., 1995. Biogeochemistry of a Forested Ecosystem, 2nd edition, New York, Springer-Verlag.

Lovett, G.M., Traynor, M.M., Pouyat, R.V., Carreiro, M.M., Zhu, W., Baxter, J.W., 2000. Atmospheric deposition to oak forests along an urban-rural gradient, Environmental Science \& Technology, 34, 4294-4300.

Lowrance, R., Todd, R., Fail, J., Jr., Hendrickson, O., Jr., Leonard R., Asmussen, L., 1984. Riparian forests as nutrient filters in agricultural watersheds, BioScience, 34, 374-377.

Machlis, G.E., Force, J.E., Burch, W.R., Jr., 1997. The human ecosystem, Part I: the human ecosystem as an organizing concept in ecosystem management, Society and Natural Resources, 10, 4, 347-367.

Maryland Department of Planning, 1999. Multi-resolution land characteristics, Maryland property view. Annapolis, Maryland.

McDonnell, M.J., Pickett, S.T.A., 1990. Ecosystem structure and function along urban-rural gradients: an unexploited opportunity for ecology, Ecology, 71, 1232-1237.

McDonnell, M.J., Pickett, S.T.A., Pouyat, R.V., Parmelee, R.W., Carreiro, M.M., 1997. Ecosystem processes along an urbanto-rural gradient, Urban Ecosystems, 1, 21-36.

McIntyre, N.E., Knowles-Yanez, K., Hope, D., 2000. Urban ecology as an interdisciplinary field: differences in the use of "urban" between the social and natural sciences, Urban Ecosystems, 4, 5-24.

Medley, K.E., McDonnell, M.J., Pickett, S.T.A., 1995. Forestlandscape structure along an urban-to-rural gradient, Professional Geographer, 47, 159-168.

Naiman, R.J., Décamps, H., 1997. The ecology of interfaces: riparian zones, Annual Review of Ecology and Systematics, 28, 621-658.

Nilon, C. H., Berkowitz, A. R., Hollweg, K. S., 2003. Introduction: ecosystem understanding is a key to understanding cities, in Berkowitz, A.R., Nilon, C.H., Hollweg, K.S. (Eds), Understanding Urban Ecosystems: A New Frontier for Science and Education, New York, Springer-Verlag, 1-13.

Peterjohn, W.T., Correll, D.L., 1984. Nutrient dynamics in an agricultural watershed: observations on the role of a riparian forest, Ecology, 65, 1466-1475.

Pickett, S.T.A., White, P.S. (Eds), 1985. The Ecology of Natural Disturbance and Patch Dynamics, Orlando (FL), Academic Press.

Pickett, S.T.A., Burch, W.R., Jr., Dalton, S.D., Foresman, T.W., 1997. Integrated urban ecosystem research, Urban Ecosystems, 1, 183-184.

Pickett, S.T.A., Cadenasso, M.L., Grove, J.M., Nilon, C.H., Pouyat, R.V., Zipperer, W.C., Costanza, R., 2001. Urban ecological systems: linking terrestrial ecological, physical, and socioeconomic components of metropolitan areas, Annual Review of Ecology and Systematics, 32, 127-157.

Pouyat, R.V., McDonnell, M.J., Pickett, S.T.A., 1997. Litter decomposition and nitrogen mineralization in oak stands along an urban-rural land use gradient, Urban Ecosystems, $1,117-131$. 
Stearns, F., Montag, T., 1974. The Urban Ecosystem: A Holistic Approach, Stroudsburg (PA), Dowden Hutchinson \& Ross.

Steinberg, D.A., Pouyat, R.V., Parmelee, R.W., Groffman, P.M., 1997. Earthworm abundance and nitrogen mineralization rates along an urban-rural land use gradient, Soil Biology and Biogeochemistry, 29, 427-430.

Sukopp, H., Hejny, S., Kowarik, I. (Eds), 1990. Urban Ecology: Plants and Plant Communities in Urban Environments, The Hague, SPB Academic Publishing.

Received 18 Februrary 2005. Accepted 2 June 2005.
Theobald, D.M., 2004. Placing exurban land-use change in a human modification framework, Frontiers in Ecology and Environment, 2, 139-144.

United Nations, 2001. Demographic Yearbook, New York, United Nations Statistics Division.

US Census Bureau, 1995. Urban and Rural Definitions.

Vincent, G., Bergeron, Y., 1985. Weed synecology and dynamics in urban environment, Urban Ecology, 9, 161-175.

Zhu, W.X., Barreiro, M.M., 1999. Chemoautotrophic nitrification in acidic soils along an urban-to-rural transect, Soil Biology and Biochemistry, 31, 1091-1100.

To access this journal online: www.edpsciences.org 